\section{Penyaluran Pembiayaan dan Non Performance financing Bank Umum Syariah di Pulau Jawa Tahun 2019}

\author{
Nur Wachidah Yulianti \\ UIN Syarif Hidayatullah Jakarta \\ wachi@uinjkt.ac.id
}

\begin{abstract}
Abstrak
Perbankan merupakan salah satu industri di sektor ekonomi tersier yang bertumbuh pesat. Secara rinci, per April 2019, kredit investasi tumbuh $14,34 \%$, kredit modal kerja tumbuh 10,48\%, sedangkan kredit konsumsi tumbuh $9 \%$ secara tahunan. Namun sayangnya pertumbuhan ini masih terkonsentrasi di Pulau Jawa. Begitupula sebaran pembiayaan yang dilakukan oleh perbankan syariah. Tercatat, sampai saat ini, sebaran pembiayaannya juga masih terkonsentrasi di Pulau Jawa, yakni sebesar 71,19 persen, khususnya DKI Jakarta sebesar 40,19 persen. Berdasarkan hal tersebut, penelitian ini bertujuan untuk melihat bagaimana sebaran pembiayaan dan Non Performing Financing (NPF) yang dilakukan oleh Bank Umum Syariah di Pulau Jawa dari Bulan Januari hingga September 2019 dari sisi modal kerja syariah, investasi syariah dan konsumsi syariah, adakah perbedaan rata-rata (mean difference) penyaluran pembiayaan dan NPF pada semua provinsi di Pulau Jawa? Populasi penelitian ini sebanyak 6 provinsi yang ada di Pulau Jawa dari Januari sampai dengan September 2019. Pengujian data penelitian ini melalui uji one way Analysis of Variance (ANOVA). Hasil uji one way ANOVA menunjukkan bahwa semua provinsi yang terdapat di Pulau Jawa secara statistik, berbeda signifikan dalam rata-rata pembiayaan modal kerja syariah. NPF modal kerja syariah, provinsi Jawa Tengah dan Banten tidak berbeda secara statistik. Pembiayaan investasi syariah, provinsi Banten dan DI Yogyakarta yang tidak berbeda secara statistik. NPF investasi syariah, ada beda yang signifikan secara statistik pada semua provinsi di Pulau Jawa. Pembiayaan dan NPF konsumsi syariah, DKI Jakarta dengan Jawa Barat, rata-rata pembiayaan dan NPF konsumsi syariah secara statistik tidak berbeda.
\end{abstract}

Kata Kunci ANOVA, pembiayaan, non performing financing

\section{PENDAHULUAN}

Seperti diketahui bahwa dari 237.641.326 jiwa penduduk Indonesia, 57,48\% penduduk terpusat di Pulau Jawa, yaitu sebesar 136.610.590 jiwa. Jika dilihat dari luas wilayahnya, luas Pulau Jawa hanya sebesar 7\% dari luas wilayah Indonesia. Namun luas pulau yang terbilang kecil tersebut tidak menghalangi penduduk pulau lain untuk berurbanisasi. Hal ini, tidak lain dan tidak bukan, karena terpusatnya pembangunan sektor ekonomi di Pulau Jawa (Wilandari, 2015). Fakta ini diperkuat oleh Badan Pusat Statistik (BPS) yang 
menyatakan bahwa penyumbang pertumbuhan ekonomi kuartal II 2018 masih didominasi dari wilayah Jawa dan Sumatera masing-masing sebesar 3,35\% dan 0,99\% (Movanita, 2018). Bahkan BPS melaporkan struktur ekonomi Indonesia secara spasial pada kuartal II-2019 didominasi oleh kelompok provinsi di Pulau Jawa. Kelompok provinsi di Pulau Jawa memberikan kontribusi terbesar terhadap produk domestik bruto (PDB) Indonesia sepanjang April-Juni 2019, yakni sebesar 59,11\% (Santoso, 2019). Selain itu, Kementerian Perindustrian juga mengakui bahwa 70 persen pengembangan industri masih berfokus di Pulau Jawa, dan 55 persen dari bagian tersebut ada di Jawa Barat dan Banten (Situmorang, 2017).

Meskipun pulau Jawa bukanlah pulau terbesar di Indonesia, namun Pulau ini menjadi pusat pertumbuhan industri Indonesia, seperti Jawa Tengah, Daerah Istimewa Yogyakarta, dan Jawa Timur. Pulau Jawa mengendalikan hingga 60\% aktivitas eksporimpor nasional. Pertumbuhan ekonominya cenderung terpusat pada produk jasa karena didukung oleh perkembangan sarana dan prasarana yang menunjang kegiatan ekonominya (Tambunan, 2015). Produk jasa merupakan salah satu dari ragam sektor ekonomi tersier selain sektor perdagangan, sektor pengangkutan dan sektor keuangan. Berdasarkan kelas sektor ekonomi, yang meliputi sektor ekonomi primer, sekunder dan tersier, secara spasial sektor ekonomi primer didominasi oleh pulau di luar pulau Jawa yaitu sebesar 73,8\%, sementara sektor ekonomi sekunder dan sektor ekonomi tersier lebih didominasi oleh Pulau Jawa yaitu sebesar 66,08\% dan 66,11\% (Wilandari, 2015).

Perbankan merupakan salah satu industri di sektor ekonomi tersier yang bertumbuh pesat. Per April 2019, pertumbuhan kredit perbankan mencapai 11,05\% secara tahunan. Dalam dua tahun terakhir, terdapat perubahan akselerasi pertumbuhan kredit dari sisi penggunaan. Secara rinci, per April 2019, kredit investasi tumbuh 14,34\%, kredit modal kerja tumbuh 10,48\%, sedangkan kredit konsumsi tumbuh $9 \%$ secara tahunan. Meski pertumbuhan kredit berangsur menguat, risiko kredit relatif terkendali, bahkan cenderung menurun. Per April 2019, rasio kredit bermasalah (Non Performing Loan) sebesar 2,56\% dan rasio pembiayaan bermasalah (Non Performing Financing) sebesar 2,76\% (Victoria, 2019). Jika dilihat dari wilayah, Per 23 Mei 2019, Otoritas Jasa Keuangan (OJK) menyebut bahwa $90 \%$ penyaluran pinjaman masih berada di Pulau Jawa. Per 23 Mei 2019, penyaluran pinjaman di luar Pulau Jawa hanya Rp 5,2 triliun, sedangkan di Pulau Jawa Rp 31,8 triliun (Annur, 2019).

Tak terkecuali pada sektor perbankan syariah. Perbankan syariah yang terbagi menjadi Bank Umum Syariah (BUS) dan Bank Pembiayaan Rakyat Syariah (BPRS), sampai saat ini, sebaran pembiayaannya juga masih terkonsentrasi di Pulau Jawa, yakni sebesar 71,19 persen, khususnya DKI Jakarta sebesar 40,19 persen (Malik, 2017). Pembiayaan pada BUS dan BPRS yang diatur dalam UU No 21 Tahun 2008 tentang Perbankan Syariah merupakan penyediaan dana atau tagihan yang dipersamakan dengan itu berupa transaksi bagi hasil dalam bentuk mudharabah dan musyarakah, transaksi sewa menyewa dalam bentuk ijarah atau sewa beli dalam bentuk ijarah muntahiya bittamlik, transaksi jual beli dalam bentuk piutang murabahah, salam dan istishna', transaksi pinjam meminjam dalam bentuk piutang qordh, dan transaksi sewa menyewa jasa dalam bentuk ijarah untuk transaksi multijasa. Semua pembiayaan tersebut secara garis besar merupakan 
pembiayaan yang disediakan bank umum syariah untuk memenuhi kebutuhan akan modal kerja, investasi dan bahkan konsumsi para nasabahnya.

Lantas bagaimanakah pertumbuhan pembiayaan BUS di Pulau Jawa pada tahun 2019? Adakah perbedaan pertumbuhan pembiayaan dan rasio pembiayaan bermasalah (Non Performing Financing) modal kerja, investasi dan konsumsi pada BUS di Pulau Jawa pada tahun 2019? Dengan rentang waktu dari Januari sampai dengan September 2019 pada 6 (enam) provinsi yang terdapat di Pulau Jawa, penelitian ini mencoba menjawab pertanyaan yang sudah disampaikan sebelumnya. Data penelitian ini berupa data pembiayaan dan non performing financing pada BUS yang diperoleh dari Statistik Perbankan Syariah September 2019 yang diunduh dari laman www.ojk.go.id

\section{LANDASAN TEORI}

\section{Jenis pembiayaan dan Non Performing Financing pada perbankan syariah}

Jenis pembiayaan pada perbankan syariah meliputi 3 jenis pembiayaan antara lain (Hadijah, 2017):

a. Pembiayaan Modal Kerja Syariah

Merupakan pembiayaan atau penyediaan dana oleh bank dengan periode waktu pendek atau panjang yang diperuntukkan bagi para pengusaha yang membutuhkan tambahan modal kerja sesuai dengan prinsip-prinsip syariah. Program pembiayaan modal kerja syariah bisa didapatkan bagi mereka yang membuka atau memiliki usaha yang dinilai bisa memiliki prospek, tidak melanggar syariat islam, dan tidak melanggar peraturan yang berlaku. Menurut data OJK, Pembiayaan modal kerja syariah yang tercatat dalam statistik perbankan syariah terdiri dari pembiayaan modal kerja syariah untuk Usaha Mikro Kecil dan Menengah (UMKM) dan Bukan UMKM.

Pada pembiayaan modal kerja ini, akad yang biasa dipergunakan adalah akad jual beli (murabahah) atau akad kerja sama (mudharabah atau musyarakah). Pada akad murabahah, biasanya bank memberikan pembiayaan modal kerja berupa penyediaan aset, dengan skema pembayaran harga pokok aset ditambah dengan margin atau keuntungan bank. Sedangkan pada akad kerja sama (mudharabah atau musyarakah), biasanya bank memberikan dana sebagai modal. Skema pembayaran berupa pengembalian pokok ditambah dengan bagi hasil bank.

Melalui pembiayaan syariah melalui akad murabahah, nasabah bisa merasakan manfaat lebih daripada kredit di bank umum konvensional karena nilai angsuran tetap sampai dengan periode perjanjian berakhir. Sedangkan untuk manfaat menggunakan pembiayaan syariah dengan akad mudharabah atau musyarakah, maka nasabah bisa mendapatkan mekanisme pembayaran yang lebih fleksibel sesuai dengan keuntungan usaha.

b. Pembiayaan Investasi Syariah

Pembiayaan investasi syariah merupakan pembiayaan jangka pendek atau jangka panjang untuk melakukan pembelian barang-barang modal yang diperlukan dalam membuka atau mendirikan usaha baru, relokasi proyek, ekspansi ataupun penggantian mesin-mesin pabrik. Menurut data OJK, Pembiayaan investasi syariah yang tercatat dalam statistik perbankan syariah terdiri dari pembiayaan investasi syariah untuk Usaha Mikro Kecil dan Menengah (UMKM) dan Bukan UMKM.

Dalam pembiayaan investasi, ada 3 jenis akad yang sering digunakan, yakni akad murabahah, ijarah atau ijarah muntahiya bit tamlik (IMBT). Ijarah merupakan akad 
dimana bank menyediakan dana dalam rangka memindahkan hak guna atau manfaat dari suatu barang atau jasa berdasarkan transaksi sewa tanpa diikuti dengan pemindahan kepemilikan barang itu sendiri. Sedangkan akad ijarah muntahiya bit tamlik (IMBT) sama seperti akad ijarah namun terdapat opsi pemindahan kepemilikan barang. Skema pembayaran dengan akad ijarah ataupun IMBT adalah pengembalian pokok ditambah ujroh (fee).

c. Pembiayaan Konsumsi Syariah

Pembiayaan konsumtif syariah merupakan pembiayaan yang diperuntukkan bagi nasabah dengan tujuan di luar usaha dan bersifat perorangan. Berbeda dengan pembiayaan syariah untuk modal kerja yang bersifat produktif, pembiayaan konsumtif diperlukan oleh nasabah untuk memenuhi kebutuhan sekunder. Jenis akad yang paling sering digunakan dalam produk pembiayaan konsumtif syariah ada dua yaitu akad murabahah dan akad ijarah.

Setiap pemberian pembiayaan yang dilakukan oleh perbankan syariah baik berupa pembiayaan modal kerja, investasi bahkan konsumsi tidaklah luput dari yang namanya "pembiayaan bermasalah". "Pembiayaan bermasalah" atau Non Performing Financing (NPF) merupakan keadaaan dimana nasabah yang menerima pembiayaan dari perbankan syariah tidak lancar dalam mengembalikan pokok serta margin atau ujroh (fee) atau bagi hasil yang sudah menjadi kewajiban nasabah kepada perbankan syariah.

\section{METODOLOGI PENELITIAN}

Untuk menjawab pertanyaan peneltian di atas, maka digunakan Uji One Way Analysis of Variance (ANOVA). Teknik ini digunakan karena penelitian ini menguji perbedaan ratarata pembiayaan modal kerja, investasi dan konsumsi provinsi yang ada di Pulau Jawa dan Non Performing Financing (NPF) provinsi yang ada di Pulau Jawa pada tahun 2019. Dengan alpha $\alpha 5 \%$, maka keputusan untuk tidak menerima $\mathrm{H}_{0}$ apabila $p$ value $>0,05$. Data pembiayaan dan non performing financing keenam provinsi yang ada di Pulau Jawa tersebut diolah melalui aplikasi SPSS ver 22.

Prinsip Uji ANOVA adalah melakukan analisis variabilitas data menjadi dua sumber variasi yaitu variasi di dalam kelompok (within) dan variasi antar kelompok (between). Bila variasi within dan between sama (nilai perbandingan kedua varian mendekati angka satu), maka berarti tidak ada perbedaan efek dari intervensi yang dilakukan, dengan kata lain nilai mean yang dibandingkan tidak ada perbedaan. Sebaliknya bila variasi antar kelompok lebih besar dari variasi di dalam kelompok, artinya intervensi tersebut memberikan efek yang berbeda, dengan kata lain nilai mean yang dibandingkan menunjukkan adanya perbedaan (Hidayat, 2017).

Sebelum dilakukan uji ANOVA terlebih dahulu akan dilakukan uji homogeneity of variance. Uji ini dilakukan untuk melihat kesamaan varian dari data. Setelah dilakukan uji homogeneity of variance, maka dapat dilakukan uji ANOVA yang berfungsi untuk melihat ada tidaknya perbedaan rata-rata (mean difference) tingkat pembiayaan modal kerja, investasi dan konsumsi keenam provinsi yang ada di Pulau Jawa tersebut dan non performing financing (NPF) keenam provinsi yang ada di Pulau Jawa tersebut. Jika terdapat perbedaan maka selanjutnya dilakukan uji post hoc test yang terdiri dari dua jenis yaitu uji Bonferroni dan uji Gomes-Howell. Apabila varian data homogen, maka uji 
Bonferroni yang digunakan, namun apabila varian data tidak homogen, maka digunakan uji Gomes-Howell (Hidayat, 2017).

\section{HASIL PENELITIAN}

Untuk menjawab pertanyaan penelitian yang telah dipaparkan sebelumnya, maka hasil penelitian ini akan dibahas menjadi 3 bagian yang terdiri dari 1) pembiayaan modal kerja syariah dan NPF nya; 2) pembiayaan investasi syariah dan NPF nya; dan 3) pembiayaan konsumsi syariah dan NPF nya.

\section{Pembiayaan dan NPF modal kerja syariah}

Pembiayaan dan NPF modal kerja syariah pada provinsi yang ada di Pulau Jawa selama bulan Januari sampai dengan September 2019 sebagaimana terlihat dalam tabel 1.

Tabel 1. Pembiayaan dan NPF modal kerja syariah provinsi di Pulau Jawa Tahun 2019

\begin{tabular}{lllccc}
\hline & \multicolumn{1}{c}{$\begin{array}{c}\text { Nama } \\
\text { Provinsi }\end{array}$} & N & $\begin{array}{c}\text { Nilai Rata- } \\
\text { rata }^{*}\end{array}$ & $\begin{array}{c}\text { Nilai } \\
\text { Minimum }\end{array}$ & $\begin{array}{c}\text { Nilai } \\
\text { Maksimum }\end{array}$ \\
\hline $\begin{array}{l}\text { Pembiayaan } \\
\text { Modal Kerja } \\
\text { Syariah }\end{array}$ & Jawa Barat & 9 & $7.233,66$ & 7.045 & 7.420 \\
\cline { 2 - 6 } & Banten & 9 & $1.309,78$ & 1.203 & 1.389 \\
\cline { 2 - 6 } & DKI Jakarta & 9 & $38.432,67$ & 35.270 & 40.505 \\
\cline { 2 - 6 } & DI Yogyakarta & 9 & 502,11 & 481 & 520 \\
\hline NPF Modal & Jawa Tengah & 9 & $5.709,67$ & 5.313 & 6.113 \\
\cline { 2 - 6 } Kerja Syariah & Jawa Timur & 9 & $8.518,78$ & 8.410 & 8.708 \\
\cline { 2 - 6 } & Jawa Barat & 9 & 322,78 & 288 & 371 \\
\cline { 2 - 6 } & Banten & 9 & 133,33 & 129 & 138 \\
& DKI Jakarta & 9 & 913,56 & 692 & 1.064 \\
\cline { 2 - 6 } & DI Yogyakarta & 9 & 12,56 & 9 & 14 \\
\hline & Jawa Tengah & 9 & 138,78 & 121 & 620 \\
\hline
\end{tabular}

Sumber: Data hasil SPSS diolah

*) disajikan dalam milyar rupiah

Berdasarkan tabel 1 diketahui bahwa provinsi DKI Jakarta mendominasi pemberian pembiayaan modal kerja syariah oleh BUS selama bulan Januari sampai dengan September 2019 dengan rata-rata pembiayaan modal kerja sebesar Rp.38.432,67 milyar dan NPF modal kerja syariah juga didominasi oleh provinsi DKI Jakarta dengan rata-rata NPF sebesar Rp.913,56 milyar.

Syarat dilakukan uji one way ANOVA adalah varians data yang sama (homogeneity of variances). Nilai signifikansi sig ( $p$ value) $>0.05$ menunjukkan kelompok data berasal dari populasi yang memiliki varians yang sama (homogen)

Tabel 2. Hasil Uji homogeneity of variances

\begin{tabular}{lccc}
\hline & Levene Statistic & Sig $(\boldsymbol{p}$-value $)$ & Keputusan \\
\hline $\begin{array}{l}\text { Pembiayaan Modal } \\
\text { Kerja Syariah }\end{array}$ & 16,993 & 0,000 & $\begin{array}{c}\text { Varian data } \\
\text { tidak homogen }\end{array}$
\end{tabular}




\section{NPF Modal Kerja}

Syariah

\section{Sumber: Data}

Varian data

0,000 tidak homogen

Oleh karena nilai Sig ( $p$-value) pada data pembiayaan modal kerja syariah dan NPF modal kerja syariah di bawah alpha $5 \%(0,000<0,05)$ maka keduanya memiliki varian data tidak homogen. Untuk melihat apakah terdapat perbedaan rata-rata nilai pembiayaan dan NPF modal kerja syariah pada provinsi di Pulau Jawa, maka dilakukan uji ANOVA. Keputusan untuk melihat ada perbedaan dapat dilihat pada nilai signifikasi (Sig) hasil uji ANOVA. Apabila nilai Sig lebih kecil dari alpha 5\% (0,05), maka terdapat perbedaan rata-rata pembiayaan dan rata-rata NPF modal kerja syariah pada provinsi di Pulau Jawa.

Tabel 3. Hasil Uji ANOVA pembiayaan dan NPF modal kerja syariah

\begin{tabular}{lcc}
\hline Pembiayaan Modal Kerja & Sig & Keputusan \\
Syariah & 0,000 & Ada Perbedaan
\end{tabular}

NPF Modal Kerja Syariah

0,000

Ada perbedaan

Sumber: Data hasil SPSS diolah

Hasil uji ANOVA sebagaimana dalam Tabel 3 menunjukkan bahwa terdapat perbedaan rata-rata pembiayaan dan NPF modal kerja syariah pada provinsi di Pulau Jawa, karena nilai sig keduanya di bawah alpha 5\% (0,05) yaitu masing-masing sebesar 0,000 $(0,000<0,05)$. Sebagaimana terlihat dalam tabel 2 , untuk pembiayaan modal kerja syariah dan NPF modal kerja syariah memiliki varian data tidak homogen, maka dilakukan uji Post Hoc Test-Gomes-Howell. Hasil uji tersebut sebagaimana terlihat dalam tabel 4.

Tabel 4. Hasil Uji Post Hoc Test - Gomes-Howell

\begin{tabular}{|c|c|c|c|c|c|}
\hline \multirow[t]{2}{*}{ Provinsi } & \multirow{2}{*}{$\begin{array}{c}\text { Terhadap } \\
\text { provinsi }\end{array}$} & \multicolumn{2}{|c|}{ Pembiavaan } & \multicolumn{2}{|r|}{ NPF } \\
\hline & & Sig & Keputusan & Sig & Keputusan \\
\hline \multirow[t]{5}{*}{ Jawa Barat } & Banten & $0,000^{*}$ & Berbeda & $0,000^{*}$ & Berbeda \\
\hline & DKI Jakarta & $0,000^{*}$ & Berbeda & $0,000^{*}$ & Berbeda \\
\hline & DI Yogyakarta & $0,000^{*}$ & Berbeda & $0,000^{*}$ & Berbeda \\
\hline & Jawa Tengah & $0,000^{*}$ & Berbeda & $0,000^{*}$ & Berbeda \\
\hline & Jawa Timur & $0,000^{*}$ & Berbeda & $0,000^{*}$ & Berbeda \\
\hline \multirow[t]{5}{*}{ Banten } & Jawa Barat & $0,000^{*}$ & Berbeda & $0,000^{*}$ & Berbeda \\
\hline & DKI Jakarta & $0,000^{*}$ & Berbeda & $0,000^{*}$ & Berbeda \\
\hline & DI Yogyakarta & $0,000^{*}$ & Berbeda & $0,000^{*}$ & Berbeda \\
\hline & Jawa Tengah & $0,000^{*}$ & Berbeda & 0,411 & Tidak berbeda \\
\hline & Jawa Timur & $0,000^{*}$ & Berbeda & $0,000^{*}$ & Berbeda \\
\hline \multirow[t]{5}{*}{ DKI Jakarta } & Jawa Barat & $0,000^{*}$ & Berbeda & $0,000^{*}$ & Berbeda \\
\hline & Banten & $0,000^{*}$ & Berbeda & $0,000^{*}$ & Berbeda \\
\hline & DI Yogyakarta & $0,000^{*}$ & Berbeda & $0,000^{*}$ & Berbeda \\
\hline & Jawa Tengah & $0,000^{*}$ & Berbeda & $0,000^{*}$ & Berbeda \\
\hline & Jawa Timur & $0,000^{*}$ & Berbeda & $0,001^{*}$ & Berbeda \\
\hline DI Yogyakarta & Jawa Barat & $0,000^{*}$ & Berbeda & $0,000^{*}$ & Berbeda \\
\hline
\end{tabular}




\begin{tabular}{cccccc}
\hline & Banten & $0,000^{*}$ & Berbeda & $0,000^{*}$ & Berbeda \\
\hline & DKI Jakarta & $0,000^{*}$ & Berbeda & $0,000^{*}$ & Berbeda \\
\hline & Jawa Tengah & $0,000^{*}$ & Berbeda & $0,000^{*}$ & Berbeda \\
\hline Jawa Tengah & Jawa Timur & $0,000^{*}$ & Berbeda & $0,000^{*}$ & Berbeda \\
\hline & Jawa Barat & $0,000^{*}$ & Berbeda & $0,000^{*}$ & Berbeda \\
\hline & Banten & $0,000^{*}$ & Berbeda & 0,411 & Tidak berbeda \\
\hline & DKI Jakarta & $0,000^{*}$ & Berbeda & $0,000^{*}$ & Berbeda \\
\hline Jawa Timur & DI Yogyakarta & $0,000^{*}$ & Berbeda & $0,000^{*}$ & Berbeda \\
\hline & Jawa Timur & $0,000^{*}$ & Berbeda & $0,000^{*}$ & Berbeda \\
\hline & Jawa Barat & $0,000^{*}$ & Berbeda & $0,000^{*}$ & Berbeda \\
\hline & Banten & $0,000^{*}$ & Berbeda & $0,000^{*}$ & Berbeda \\
\hline & DKI Jakarta & $0,000^{*}$ & Berbeda & $0,001^{*}$ & Berbeda \\
\hline & DI Yogyakarta & $0,000^{*}$ & Berbeda & $0,000^{*}$ & Berbeda \\
\hline
\end{tabular}

Sumber: Data hasil SPSS diolah

*) Perbedaan rata-rata (mean difference) signifikan pada level (alpha) 0,05 (5\%)

Berdasarkan tabel 4, dapat disimpulkan bahwa semua provinsi di Pulau Jawa memiliki perbedaan rata-rata yang signifikan secara statistik dalam pembiayaan modal kerja syariah. Sedangkan untuk NPF modal kerja syariah, ada beda yang signifikan secara statistik nilai rata-rata NPF di antara provinsi di Pulau Jawa kecuali Jawa Tengah dan Banten yang tidak berbeda secara statistik karena nilai sig kedua provinsi tersebut di atas alpha $5 \%(0,411>0,05)$.

Pada provinsi Banten dan Jawa Tengah, walaupun dalam sisi pembiayaan modal kerja syariah, terdapat perbedaan rata-rata yang signifikan secara statistik, namun pada sisi NPF modal kerja syariah tidak terdapat beda rata-rata yang signifikan secara statistik. Artinya, angka rata-rata pembiayaan modal kerja syariah pada provinsi Banten (Rp.1.309,77 milyar) dan provinsi Jawa Tengah (Rp.5.709,66 milyar) yang terdapat dalam tabel 1 memang secara statistik signifikan berbeda, namun angka rata-rata NPF modal kerja syariah provinsi Banten (Rp.133,33 milyar) dan provinsi Jawa Tengah (Rp.138,78 milyar), dinilai secara statistik tidak berbeda.

\section{Pembiayaan dan NPF investasi syariah}

Pembiayaan dan NPF investasi syariah pada provinsi yang ada di Pulau Jawa selama bulan Januari sampai dengan September 2019 sebagaimana terlihat dalam tabel 5. Dalam tabel 5, diketahui bahwa DKI Jakarta juga mendominasi pembiayaan investasi syariah dan NPF investasi syariah dengan nilai rata-rata keduanya masing-masing Rp.27.204,67 Milyar dan Rp1.322,11 Milyar.

Tabel 5. Pembiayaan dan NPF investasi syariah provinsi di Pulau Jawa Tahun 2019

\begin{tabular}{lcccc}
$\begin{array}{c}\text { Nama } \\
\text { Provinsi }\end{array}$ & N & $\begin{array}{c}\text { Nilai Rata- } \\
\text { rata }^{*}\end{array}$ & $\begin{array}{c}\text { Nilai } \\
\text { Minimum }\end{array}$ & $\begin{array}{c}\text { Nilai } \\
\text { Maksimum }^{*}\end{array}$ \\
\hline Jawa Barat & 9 & $4.148,78$ & 4.083 & 4.223 \\
\hline Banten & 9 & 760,33 & 719 & 807 \\
\hline
\end{tabular}




\begin{tabular}{lllccc}
\hline $\begin{array}{l}\text { Pembiayaan } \\
\text { Investasi } \\
\text { Syariah }\end{array}$ & DKI Jakarta & 9 & $27.204,67$ & 25.874 & 28.555 \\
\cline { 2 - 6 } & DI Yogyakarta & 9 & 783,44 & 762 & 793 \\
\cline { 2 - 6 } & Jawa Tengah & 9 & $2.505,67$ & 2.309 & 2.612 \\
\cline { 2 - 6 } $\begin{array}{l}\text { NPF Investasi } \\
\text { Syariah }\end{array}$ & Jawa Timur & 9 & $6.388,37$ & 2.856 & 3.025 \\
\cline { 2 - 6 } & Jawa Barat & 9 & 150,22 & 141 & 159 \\
\cline { 2 - 6 } & Banten & 9 & 35,22 & 21 & 51 \\
\cline { 2 - 6 } & DKI Jakarta & 9 & $1.322,11$ & 1.242 & 1.384 \\
\cline { 2 - 6 } & DI Yogyakarta & 9 & 13,56 & 11 & 27 \\
\hline & Jawa Tengah & 9 & 233,11 & 216 & 260 \\
\hline
\end{tabular}

Sumber: Data hasil SPSS diolah

*) disajikan dalam milyar rupiah

Syarat dilakukan uji one way ANOVA adalah varians data yang sama (homogeneity of variances). Nilai signifikansi sig ( $p$ value) $>0.05$ menunjukkan kelompok data berasal dari populasi yang memiliki varians yang sama (homogen)

Tabel 6. Hasil Uji homogeneity of variances

\begin{tabular}{lccc}
\hline & Levene Statistic & Sig $(\boldsymbol{p}$-value $)$ & Keputusan \\
\hline $\begin{array}{l}\text { Pembiayaan Investasi } \\
\text { Syariah }\end{array}$ & 7,719 & 0,000 & $\begin{array}{c}\text { Varian data } \\
\text { tidak homogen }\end{array}$ \\
$\begin{array}{l}\text { NPF Investasi Syariah } \\
\text { Sulata }\end{array}$ & 9,914 & 0,000 & $\begin{array}{c}\text { Varian data } \\
\text { tidak homogen }\end{array}$ \\
\hline
\end{tabular}

Sumber: Data hasil SPSS diolah

Oleh karena nilai Sig ( $p$-value) pada pembiayaan investasi syariah dan NPF investasi syariah di bawah alpha 5\% $(0,000<0,05)$, sebagaimana terlihat dalam tabel 6 , maka keduanya memiliki varian data tidak homogen. Untuk melihat apakah ada perbedaan ratarata pembiayaan dan rata-rata NPF investasi syariah pada provinsi di Pulau Jawa, maka dilakukan uji ANOVA. Keputusan untuk melihat ada perbedaan dapat dilihat pada nilai signifikasi (Sig) hasil uji ANOVA. Apabila nilai Sig lebih kecil dari alpha 5\% $(0,05)$, maka terdapat perbedaan rata-rata pembiayaan dan NPF investasi syariah pada provinsi di Pulau Jawa.

Tabel 7. Hasil Uji ANOVA pembiayaan dan NPF investasi syariah

\begin{tabular}{lcc}
\hline & Sig & Keputusan \\
\hline Pembiayaan Investasi Syariah & 0,000 & Ada Perbedaan \\
NPF Investasi Syariah & 0,000 & Ada perbedaan \\
\hline Sul
\end{tabular}

Sumber: Data hasil SPSS diolah

Hasil uji ANOVA sebagaimana dalam tabel 7 menunjukkan bahwa terdapat perbedaan rata-rata yang signifikan secara statistik pada pembiayaan dan NPF investasi syariah pada provinsi di Pulau Jawa, karena nilai sig di bawah alpha 5\% $(0,05)$ yaitu masing-masing sebesar $0,000(0,000<0,05)$. Sebagaimana terlihat dalam tabel 6 , untuk pembiayaan investasi syariah dan NPF investasi syariah memiliki varian data tidak homogen, maka 
dilakukan uji Post Hoc Test - Gomes-Howell. Hasil uji tersebut sebagaimana terlihat dalam tabel 8 .

Tabel 8. Hasil Uji Post Hoc Test - Gomes-Howell

\begin{tabular}{|c|c|c|c|c|c|}
\hline \multirow[t]{2}{*}{ Provinsi } & \multirow{2}{*}{$\begin{array}{c}\text { Terhadap } \\
\text { provinsi }\end{array}$} & \multicolumn{2}{|c|}{ Pembiayaan } & \multicolumn{2}{|r|}{ NPF } \\
\hline & & Sig & Keputusan & Sig & Keputusan \\
\hline \multirow[t]{5}{*}{ Jawa Barat } & Banten & $0,000^{*}$ & Berbeda & $0,000^{*}$ & Berbeda \\
\hline & DKI Jakarta & $0,000^{*}$ & Berbeda & $0,000^{*}$ & Berbeda \\
\hline & DI Yogyakarta & $0,000^{*}$ & Berbeda & $0,000^{*}$ & Berbeda \\
\hline & Jawa Tengah & $0,000^{*}$ & Berbeda & $0,000^{*}$ & Berbeda \\
\hline & Jawa Timur & $0,000^{*}$ & Berbeda & $0,000^{*}$ & Berbeda \\
\hline \multirow[t]{5}{*}{ Banten } & Jawa Barat & $0,000^{*}$ & Berbeda & $0,000^{*}$ & Berbeda \\
\hline & DKI Jakarta & $0,000^{*}$ & Berbeda & $0,000^{*}$ & Berbeda \\
\hline & DI Yogyakarta & 0,455 & Tidak Berbeda & $0,000^{*}$ & Berbeda \\
\hline & Jawa Tengah & $0,000^{*}$ & Berbeda & $0,000^{*}$ & Berbeda \\
\hline & Jawa Timur & $0,000^{*}$ & Berbeda & $0,000^{*}$ & Berbeda \\
\hline \multirow[t]{5}{*}{ DKI Jakarta } & Jawa Barat & $0,000^{*}$ & Berbeda & $0,000^{*}$ & Berbeda \\
\hline & Banten & $0,000^{*}$ & Berbeda & $0,000^{*}$ & Berbeda \\
\hline & DI Yogyakarta & $0,000^{*}$ & Berbeda & $0,000^{*}$ & Berbeda \\
\hline & Jawa Tengah & $0,000^{*}$ & Berbeda & $0,000^{*}$ & Berbeda \\
\hline & Jawa Timur & $0,000^{*}$ & Berbeda & $0,000^{*}$ & Berbeda \\
\hline \multirow[t]{5}{*}{ DI Yogyakarta } & Jawa Barat & $0,000^{*}$ & Berbeda & $0,000^{*}$ & Berbeda \\
\hline & Banten & 0,455 & Tidak Berbeda & $0,000^{*}$ & Berbeda \\
\hline & DKI Jakarta & $0,000^{*}$ & Berbeda & $0,000^{*}$ & Berbeda \\
\hline & Jawa Tengah & $0,000^{*}$ & Berbeda & $0,000^{*}$ & Berbeda \\
\hline & Jawa Timur & $0,000^{*}$ & Berbeda & $0,000^{*}$ & Berbeda \\
\hline \multirow[t]{5}{*}{ Jawa Tengah } & Jawa Barat & $0,000^{*}$ & Berbeda & $0,000^{*}$ & Berbeda \\
\hline & Banten & $0,000^{*}$ & Berbeda & $0,000^{*}$ & Berbeda \\
\hline & DKI Jakarta & $0,000^{*}$ & Berbeda & $0,000^{*}$ & Berbeda \\
\hline & DI Yogyakarta & $0,000^{*}$ & Berbeda & $0,000^{*}$ & Berbeda \\
\hline & Jawa Timur & $0,000^{*}$ & Berbeda & $0,000^{*}$ & Berbeda \\
\hline \multirow[t]{5}{*}{ Jawa Timur } & Jawa Barat & $0,000^{*}$ & Berbeda & $0,000^{*}$ & Berbeda \\
\hline & Banten & $0,000^{*}$ & Berbeda & $0,000^{*}$ & Berbeda \\
\hline & DKI Jakarta & $0,000^{*}$ & Berbeda & $0,000^{*}$ & Berbeda \\
\hline & DI Yogyakarta & $0,000^{*}$ & Berbeda & $0,000^{*}$ & Berbeda \\
\hline & Jawa Tengah & $0,000^{*}$ & Berbeda & $0,000^{*}$ & Berbeda \\
\hline
\end{tabular}

Sumber: Data hasil SPSS diolah

*) Perbedaan rata-rata (mean difference) signifikan pada level (alpha) 0,05 (5\%)

Berdasarkan tabel 8, dapat disimpulkan bahwa semua provinsi di Pulau Jawa memiliki perbedaan rata-rata yang signifikan secara statistik dalam pembiayaan investasi syariah, kecuali pada provinsi Banten dan DI Yogyakarta yang tidak berbeda karena nilai sig kedua provinsi tersebut di atas alpha 5\% (0,455>0,05). Sedangkan untuk NPF investasi syariah, ada beda yang signifikan secara statistik atas nilai rata-rata NPF pada semua provinsi di Pulau Jawa. 
Pada provinsi Banten dan DI Yogyakarta, walaupun dalam sisi pembiayaan investasi syariah, tidak terdapat perbedaan rata-rata yang signifikan secara statistik, namun pada sisi NPF investasi terdapat beda rata-rata yang signifikan secara statistik. Artinya, angka rata-rata pembiayaan investasi syariah pada provinsi Banten (Rp.760,33 milyar) dan provinsi DI Yogyakarta (Rp.783,44 milyar) sebagaimana terdapat dalam tabel 5 tidak berbeda secara statistik, namun angka rata-rata NPF investasi syariah provinsi Banten (Rp.35,22 milyar) dan provinsi DI Yogyakarta (Rp.13,55 milyar), dinilai secara statistik berbeda signifikan.

\section{Pembiayaan dan NPF konsumsi syariah}

Pembiayaan dan NPF konsumsi syariah pada provinsi yang ada di Pulau Jawa selama bulan Januari sampai dengan September 2019 sebagaimana terlihat dalam tabel 9. Dalam tabel 9, diketahui bahwa DKI Jakarta (Rp.13.557,89 Milyar) dan Jawa Barat (Rp.13.551,67 Milyar) merupakan dua provinsi yang rata-rata pembiayaan konsumsi syariah nya hampir sama dan lebih tinggi dari provinsi lain di Pulau Jawa. Begitupula dengan rata-rata NPF konsumsi syariah DKI Jakarta dan Jawa Barat yang hampir sama dengan nilai rata-rata keduanya masing-masing Rp.301 Milyar dan Rp.315,33 Milyar.

Tabel 9. Pembiayaan dan NPF konsumsi syariah provinsi di Pulau Jawa Tahun 2019

\begin{tabular}{|c|c|c|c|c|c|}
\hline & $\begin{array}{l}\text { Nama } \\
\text { Provinsi }\end{array}$ & $\mathbf{N}$ & $\begin{array}{l}\text { Nilai Rata- } \\
\text { rata*) }^{*}\end{array}$ & $\begin{array}{c}\text { Nilai } \\
\text { Minimum }\end{array}$ & $\begin{array}{c}\text { Nilai } \\
\text { Maksimum*) }\end{array}$ \\
\hline \multirow{6}{*}{$\begin{array}{l}\text { Pembiayaan } \\
\text { Konsumsi } \\
\text { Syariah }\end{array}$} & Jawa Barat & 9 & $13.551,67$ & 12.899 & 14.246 \\
\hline & Banten & 9 & $3.883,22$ & 3.701 & 4.105 \\
\hline & DKI Jakarta & 9 & $13.557,89$ & 13.232 & 14.046 \\
\hline & DI Yogyakarta & 9 & $1.013,44$ & 981 & 1.046 \\
\hline & Jawa Tengah & 9 & $3.571,11$ & 3.459 & 3.714 \\
\hline & Jawa Timur & 9 & $6.307,67$ & 5.955 & 6.674 \\
\hline \multirow{6}{*}{$\begin{array}{l}\text { NPF Konsumsi } \\
\text { Syariah }\end{array}$} & Jawa Barat & 9 & 301,00 & 261 & 340 \\
\hline & Banten & 9 & 78,00 & 73 & 84 \\
\hline & DKI Jakarta & 9 & 315,33 & 296 & 333 \\
\hline & DI Yogyakarta & 9 & 29,78 & 23 & 34 \\
\hline & Jawa Tengah & 9 & 69,67 & 61 & 76 \\
\hline & Jawa Timur & 9 & 173,33 & 141 & 197 \\
\hline
\end{tabular}

Sumber: Data hasil SPSS diolah

*) disajikan dalam milyar rupiah

Syarat dilakukan uji one way ANOVA adalah varians data yang sama (homogeneity of variances). Nilai signifikansi sig ( $p$ value) $>0.05$ menunjukkan kelompok data berasal dari populasi yang memiliki varians yang sama (homogen)

Tabel 10. Hasil Uji homogeneity of variances

\begin{tabular}{lccc}
\hline & Levene Statistic & Sig $(\boldsymbol{p}$-value $)$ & Keputusan \\
\hline $\begin{array}{l}\text { Pembiayaan Konsumsi } \\
\text { Syariah }\end{array}$ & 6,451 & 0,000 & $\begin{array}{c}\text { Varian data } \\
\text { tidak homogen }\end{array}$
\end{tabular}




\section{NPF Konsumsi Syariah}

Sumber: Data hasil SPSS diolah
Varian data

tidak homogen

Oleh karena nilai Sig ( $p$-value) pada pembiayaan dan NPF konsumsi syariah berada di bawah alpha $5 \%(0,000<0,05)$ maka varians untuk data pembiayaan konsumsi syariah dan NPF konsumsi syariah tidak homogen. Untuk melihat apakah terdapat perbedaan pembiayaan dan NPF konsumsi syariah pada provinsi di Pulau Jawa, maka dilakukan uji ANOVA. Keputusan untuk melihat ada perbedaan dapat dilihat pada nilai signifikasi (Sig) hasil uji ANOVA. Apabila nilai Sig lebih kecil dari alpha 5\% (0,05), maka terdapat perbedaan pembiayaan dan NPF konsumsi syariah pada provinsi di Pulau Jawa.

Tabel 11. Hasil Uji ANOVA pembiayaan dan NPF konsumsi syariah

\begin{tabular}{lcc}
\hline & Sig & Keputusan \\
\hline $\begin{array}{l}\text { Pembiayaan Konsumsi } \\
\text { Syariah }\end{array}$ & 0,000 & Ada Perbedaan \\
NPF konsumsi Syariah & 0,000 & Ada perbedaan \\
\hline
\end{tabular}

Sumber: Data hasil SPSS diolah

Hasil uji ANOVA sebagaimana dalam Tabel 11 menunjukkan bahwa terdapat perbedaan rata-rata pembiayaan dan NPF konsumsi syariah pada provinsi di Pulau Jawa, karena nilai sig di bawah alpha 5\% (0,05) yaitu masing-masing sebesar $0,000 \quad(0,000<0,05)$. Sebagaimana terlihat dalam tabel 10 , untuk pembiayaan konsumsi syariah dan NPF konsumsi syariah memiliki varian data tidak homogen, maka dilakukan uji Post Hoc Test - Gomes-Howell. Hasil uji tersebut sebagaimana terlihat dalam tabel 12.

Tabel 12. Hasil Uji Post Hoc Test - Gomes-Howell

\begin{tabular}{cccccc}
\hline Provinsi & $\begin{array}{c}\text { Terhadap } \\
\text { provinsi }\end{array}$ & Sig & Keputusan & Sig & $\begin{array}{c}\text { NPF } \\
\text { Keputusan }\end{array}$ \\
\hline Jawa Barat & Banten & $0,000^{*}$ & Berbeda & $0,000^{*}$ & Berbeda \\
\hline & DKI Jakarta & 1,000 & Tidak Berbeda & 0,652 & Tidak Berbeda \\
\hline & DI Yogyakarta & $0,000^{*}$ & Berbeda & $0,000^{*}$ & Berbeda \\
\hline & Jawa Tengah & $0,000^{*}$ & Berbeda & $0,000^{*}$ & Berbeda \\
\hline Janten & Jawa Timur & $0,000^{*}$ & Berbeda & $0,000^{*}$ & Berbeda \\
\hline & Jawa Barat & $0,000^{*}$ & Berbeda & $0,000^{*}$ & Berbeda \\
\hline & DKI Jakarta & $0,000^{*}$ & Berbeda & $0,000^{*}$ & Berbeda \\
\hline & DI Yogyakarta & $0,000^{*}$ & Berbeda & $0,000^{*}$ & Berbeda \\
\hline Jawa Tengah & $0,001^{*}$ & Berbeda & $0,008^{*}$ & Berbeda \\
\hline & Jawa Timur & $0,000^{*}$ & Berbeda & $0,000^{*}$ & Berbeda \\
\hline & Jawa Barat & 1,000 & Tidak Berbeda & 0,652 & Tidak Berbeda \\
\hline & Banten & $0,000^{*}$ & Berbeda & $0,000^{*}$ & Berbeda \\
\hline & DI Yogyakarta & $0,000^{*}$ & Berbeda & $0,000^{*}$ & Berbeda \\
\hline DI Yakarta & Jawa Tengah & $0,000^{*}$ & Berbeda & $0,000^{*}$ & Berbeda \\
\hline & Jawa Timur & $0,000^{*}$ & Berbeda & $0,000^{*}$ & Berbeda \\
\hline & Jawa Barat & $0,000^{*}$ & Berbeda & $0,000^{*}$ & Berbeda \\
\hline
\end{tabular}




\begin{tabular}{cccccc}
\hline Provinsi & $\begin{array}{c}\text { Terhadap } \\
\text { provinsi }\end{array}$ & Sig & Keputusan & Sig & $\begin{array}{c}\text { NPF } \\
\text { Keputusan }\end{array}$ \\
\hline & Banten & $0,000^{*}$ & Berbeda & $0,000^{*}$ & Berbeda \\
\hline & DKI Jakarta & $0,000^{*}$ & Berbeda & $0,000^{*}$ & Berbeda \\
\hline & Jawa Tengah & $0,000^{*}$ & Berbeda & $0,000^{*}$ & Berbeda \\
\hline Jawa Tengah & Jawa Timur & $0,000^{*}$ & Berbeda & $0,000^{*}$ & Berbeda \\
\hline & Jawa Barat & $0,000^{*}$ & Berbeda & $0,000^{*}$ & Berbeda \\
\hline & Banten & $0,001^{*}$ & Berbeda & $0,008^{*}$ & Berbeda \\
\hline & DKI Jakarta & $0,000^{*}$ & Berbeda & $0,000^{*}$ & Berbeda \\
\hline Dawa Timur & Dogyakarta & $0,000^{*}$ & Berbeda & $0,000^{*}$ & Berbeda \\
\hline & Jawa Timur & $0,000^{*}$ & Berbeda & $0,000^{*}$ & Berbeda \\
\hline & Jawa Barat & $0,000^{*}$ & Berbeda & $0,000^{*}$ & Berbeda \\
\hline & Banten & $0,000^{*}$ & Berbeda & $0,000^{*}$ & Berbeda \\
\hline & DI Jakarta & $0,000^{*}$ & Berbeda & $0,000^{*}$ & Berbeda \\
\hline & Jawa Tengah & $0,000^{*}$ & Berbeda & $0,000^{*}$ & Berbeda \\
\hline
\end{tabular}

Sumber: Data hasil SPSS diolah

*) Perbedaan rata-rata (mean difference) signifikan pada level (alpha) 0,05 (5\%)

Berdasarkan tabel 12, dapat disimpulkan bahwa semua provinsi di Pulau Jawa memiliki perbedaan rata-rata yang signifikan secara statistik dalam pembiayaan konsumsi syariah, kecuali pada provinsi DKI Jakarta dan Jawa Barat yang tidak berbeda karena nilai sig kedua provinsi tersebut di atas alpha 5\% (1,000>0,05). Sedangkan untuk NPF konsumsi syariah, ada beda yang signifikan secara statistik atas nilai rata-rata NPF pada semua provinsi di Pulau Jawa kecuali pada provinsi DKI Jakarta dan Jawa Barat yang tidak berbeda karena nilai sig kedua provinsi tersebut di atas alpha 5\% $(0,652>0,05)$.

Secara angka nominal, sebagaimana terdapat dalam tabel 9, rata-rata pembiayaan konsumsi syariah provinsi Jawa Barat (Rp.13.551,67 Milyar) dan DKI Jakarta (Rp.13.557,89 Milyar) memang terdapat perbedaan atau selisih sebesar Rp.6,22 Milyar. Akan tetapi, berdasarkan uji Gomes-Howell, secara statistik, tidak ada perbedaan dalam rata-rata pembiayaan konsumsi di Jawa Barat dan DKI Jakarta. Begitupula dengan ratarata NPF konsumsi syariah pada provinsi Jawa Barat (Rp.301 Milyar) dan DKI Jakarta (Rp.315,33 Milyar), yang secara angka nominal terdapat selisih sebesar Rp.14,33 Milyar, namun secara statistik berdasarkan uji Gomes-Howell, tidak ada perbedaan dalam ratarata NPF konsumsi syariah pada kedua provinsi tersebut.

\section{KESIMPULAN}

Hasil penelitian ini menunjukan bahwa semua provinsi yang terdapat di Pulau Jawa secara statistik, berbeda signifikan dalam rata-rata pembiayaan modal kerja syariah. Namun pada NPF modal kerja syariah, provinsi Jawa Tengah dan Banten tidak berbeda secara statistik, sedangkan provinsi lainnya secara statistik memiliki perbedaan rata-rata NPF modal kerja yang signifikan. Dalam pembiayaan investasi syariah, semua provinsi di Pulau Jawa memiliki perbedaan rata-rata yang signifikan secara statistik dalam pembiayaan investasi syariah, kecuali pada provinsi Banten dan DI Yogyakarta yang tidak berbeda secara statistik. Sedangkan untuk NPF investasi syariah, ada beda yang 
signifikan secara statistik atas nilai rata-rata NPF pada semua provinsi di Pulau Jawa. Dalam hal pembiayaan dan NPF konsumsi syariah, DKI Jakarta dengan Jawa Barat, ratarata pembiayaan dan NPF konsumsi syariah secara statistik tidak berbeda, sedangkan pada provinsi lainnya rata-rata pembiayaan dan NPF konsumsi syariah secara statistik berbeda signifikan.

\section{UCAPAN TERIMA KASIH}

Puji syukur penulis panjatkan kehadirat Allah Swt, Tuhan semesta Alam, atas segala kenikmatan dan keberkahan yang diberikan sepanjang hayat. Shalawat serta salam kepada Rasulullah, Muhammad Saw, atas segala syafa'at dan kasih saying kepada seluruh umatnya. Ucapan terima kasih juga disampaikan untuk Universitas Islam Negeri (UIN) Syarif Hidayatullah Jakarta tempat penulis mengabdi saat ini, serta kepada seluruh pihakpihak yang membantu dalam proses penulisan jurnal ini.

\section{DAFTAR PUSTAKA}

Annur, C. M. (2019, Juni 15). OJK Sebut 90\% Penyaluran Pinjaman Masih di Pulau Jawa. Retrieved from katadata.co.id: https://katadata.co.id/berita/2019/06/15/ojk-sebut90-penyaluran-pinjaman-masih-di-pulau-jawa

Hadijah, S. (2017, Mei 18). Kenali Ragam Jenis Pembiayaan Syariah dan Manfaatnya. Retrieved from cermati.com: https://www.cermati.com/artikel/kenali-ragam-jenispembiayaan-syariah-dan-manfaatnya

Hidayat, A. (2017, September 18). Uji ANOVA - One Way Anova dalam SPSS. Retrieved from Statistikian: https://www.statistikian.com/2012/11/one-way-anova-dalamspss.html/amp

Malik, A. (2017, Januari 18). Aset Perbankan Syariah Masih Terkonsetrasi di Pulau Jawa. Retrieved from TEMPO.CO: https://bisnis.tempo.co/read/837211/aset-perbankansyariah-masih-terkonsetrasi-di-pulau-jawa

Movanita, A. N. (2018, Agustus 6). BPS: Pertumbuhan Ekonomi Masih Fokus di Jawa dan Sumatera. Retrieved from Kompas.com: https://ekonomi.kompas.com/read/2018/08/06/145135326/bps-pertumbuhan-ekonomimasih-fokus-di-jawa-dan-sumatera

Santoso, Y. I. (2019, Agustus 5). Jawa menjadi jawara pertumbuhan ekonomi di kuartal II 2019. Retrieved from Kontan.co.id: https://nasional.kontan.co.id/news/jawa-menjadijawara-pertumbuhan-ekonomi-di-kuartal-ii-2019

Situmorang, A. P. (2017, Maret 8). merdeka.com. Retrieved from Kemenperin: 70 persen industri ada di Jawa, ini jadi masalah: https://www.merdeka.com/uang/kemenperin-70persen-industri-ada-di-jawa-ini-jadi-masalah.html 
$\begin{array}{lllll}\text { Statistik } & \text { Perbankan } & \text { Syariah. } & \text { (Sept } & \text { 2019). }\end{array}$ https://www.ojk.go.id/id/kanal/syariah/data-dan-statistik/statistik-perbankansyariah/Pages/Stastistik-Perbankan-Syariah---September-2019.aspx

Tambunan, T. (2015, Juni 24). Indonesia atau Pulau Jawa? Retrieved from Kompasiana: https://www.kompasiana.com/theresiatambunan/552fb4ee6ea83421218b45b7/indonesia -atau-pulau-jawa

Victoria, A. O. (2019, Juni 14). OJK Lihat Potensi Kredit Tumbuh Hingga 14\% pada 2020. Retrieved from katadata.co.id: https://katadata.co.id/berita/2019/06/14/ojk-lihatpotensi-kredit-tumbuh-hingga-14-pada-2020

Wilandari, A. (2015, Juni 17). Pengaruh Jumlah Sektor Ekonomi Di Pulau Jawa Terhadap Pemusatan Penduduk Di Pulau Jawa. Retrieved from Kompasiana: https://www.kompasiana.com/ditawilandari/54f3869e745513a42b6c7914/pengaruhjumlah-sektor-ekonomi-di-pulau-jawa-terhadap-pemusatan-penduduk-di-pulau-jawa

UU NO. 21 TAHUN 2008 TENTANG PERBANKAN SYARIAH 